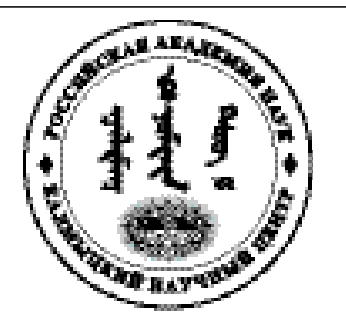

Published in the Russian Federation

Oriental Studies (Previous Name: Bulletin of the Kalmyk Institute

for Humanities of the Russian Academy of Sciences)

Has been issued as a journal since 2008

ISSN: 2619-0990; E-ISSN: 2619-1008

Vol. 13, Is. 4, pp. 951-960, 2020

DOI: $10.22162 / 2619-0990-2020-50-4-951-960$

Journal homepage: https://kigiran.elpub.ru

УДК 398

DOI: 10.22162/2619-0990-2020-50-4-951-960

\title{
Лиса в фольклоре и религиозно-магической практике башкир
}

\section{Азалия Фаттаховна Илимбетова ${ }^{1}$}

${ }^{1}$ Институт истории, языка и литературы Уфимского федерального исследовательского центра РАН (д. 71, пр. Октября, 450054 Уфа, Российская Федерация) кандидат исторических наук, старший научный сотрудник iD 0000-0001-7945-9559. E-mail: ilimbetovazalia@mail.ru

(C) КалмНЦ РАН, 2020

(C) Илимбетова А. Ф., 2020

Аннотация. Введение. Статья посвящена анализу пережитков культа лисы у башкир, которая являлась одним из почитаемых животных в их древних религиозно-мистических представлениях. Целью работы является изучение культа этого животного у башкир во всех его проявлениях в быту и хозяйственной жизни по данным фольклора, этнографии и других материалов. Материалы и методы. Основными источниками являются опубликованные этнографические, фольклорные, лингвистические сведения, а также полевые материалы автора по данной проблеме. Методологическую основу исследования составили принцип аналитического, ретроспективного и сравнительно-исторического анализа литературных, этнографических, фольклорных и лингвистических источников. Результаты. В работе впервые систематизированы и проанализированы различные материалы по культу лисы у башкир, что дает возможность воссоздать те или иные аспекты этнической истории башкирского народа, а также способствует выявлению исторических и генетических корней их духовной культуры. Введены в научный оборот новые фольклорные и этнографические сведения, переведенные автором на русский язык. Выводы. В традиционном мировоззрении башкир о лисе лежат идеи их тождества и родства друг с другом, возможности взаимного перевоплощения и отсутствия принципиальной разницы между ними - все это составляет суть древнейших представлений человека о его месте в окружающем мире. В фольклоре башкир сохранились реликты веры в происхождение отдельных их родовых групп от лисы. Лиса как тотемический предок выступает в роли покровительницы и помощницы людей, дарит им здоровье, благополучие и семейное счастье. В устной словесности башкир имеются материалы о признании лисы зооморфным божеством, хозяйкой природы и олицетворением солнца. В народной хореографии прослеживаются следы обряда, посвященного чествованию лисы как тотема и тотемического предка. В обычаях и поверьях башкир лиса как сакральное существо была табуированным животным.

Ключевые слова: башкиры, лиса, культ, верования, фольклор, мировоззрение, традиции Благодарность. Исследование проведено в рамках государственной субсидии проект «Духовная культура тюркских народов Южного Урала» (номер госрегистрации: AAAA-A17-117040350082-3). 
Для цитирования: Илимбетова А. Ф. Лиса в фольклоре и религиозно-магической практике башкир // Oriental Studies. 2020. T. 13. № 4. C. 951-960. DOI: 10.22162/2619-0990-2020-50-4$951-960$

UDC 398

DOI: $10.22162 / 2619-0990-2020-50-4-951-960$

\title{
Fox in Bashkir Folklore and Religious-Magical Practices
}

\author{
Azaliya F. Ilimbetova ${ }^{1}$ \\ ${ }^{1}$ Institute of History, Language and Literature, Ufa Federal Research Centre of the RAS (71, Oktyabrya \\ Ave., Ufa 450054, Russian Federation) \\ Cand. Sc. (History), Senior Research Associate \\ iD 0000-0001-7945-9559. E-mail: ilimbetovazalia@mail.ru
}

(C) KalmSC RAS, 2020
(C) Ilimbetova A. F., 2020

\begin{abstract}
Introduction. The article analyzes vestiges of the fox cult among Bashkirs. The animal used to be a most revered one in religious and mystical beliefs of the nation. Goals. The work seeks to study the fox cult in all its manifestations in everyday life and economic activities on the basis of folklore, ethnographic and other materials. The main sources involved are ethnographic, folklore, linguistic publications, as well as the author's field data. Methods. The research rests on theoretical, retrospective and comparative historical analyses of the mentioned sources. Results. The study is first to analyze various data on the fox cult among Bashkirs, which makes it possible to reconstruct some aspects of Bashkir ethnic history and is also instrumental in identifying the historical and genetic roots of ethnic spiritual culture. The paper employs new folklore and ethnographic materials, and introduces them into scientific discourse. Conclusions. The traditional ethnic worldview contains the idea of kinship and identity between Bashkirs and the fox; the former proclaims a possibility of mutual reincarnation and somewhat absence of any fundamental difference between the latter all this to constitute the essence of the ancient man's ideas about his place in the world. Folklore and rituals maintain vestiges of faith that individual clan groups are descended from the fox. When viewed as a totemic ancestor, the fox takes on the roles of a patroness, protector, adviser and helper of people that gives health, prosperity and family happiness. Bashkir oral literature contains materials that recognize the fox as a zoomorphic deity, the mistress of nature and personification of the sun. In everyday traditions and folk choreography, there are traces of a totemic ritual of honoring the fox as a totem and totemic ancestor. Being a sacred creature, the fox was a tabooed animal in customs and beliefs of the Bashkirs.
\end{abstract}

Keywords: Bashkirs, fox, cult, beliefs, folklore, worldview, traditions

Acknowlegdements. The reported study was funded by government subsidy — project name 'Turkic Peoples of the Southern Urals: Spiritual Culture' (state reg. no. AAAA-A17-117040350082-3).

For citation: Ilimbetova A. F. Fox in Bashkir Folklore and Religious-Magical Practices. Oriental Studies. 2020. Vol. 13(4): 951-960. (In Russ.). DOI: 10.22162/2619-0990-2020-50-4-951-960

\section{Введение}

Культ животных является наиболее важной частью древнего политеистического мировоззрения многих народов мира, в том числе и башкир. К почитаемым башкирами животным относилась лиса (төлкө), ее образ часто встречается в их религиозно-мистических представлениях, традиционном

\section{3}

мировоззрении и фольклоре [Илимбетова, Илимбетов 2012: 8-31; Семенов 1966: $332-$ 333, 434-438].

Исследование пережитков почитания лисы дает возможность воссоздать те или иные аспекты этнической истории башкирского народа, а также способствует выявлению исторических и генетических корней их 
духовной культуры. К сожалению, проблеме образа лисицы (лиса) в культуре и традиционном мировоззрении башкир до сих пор не уделялось должного внимания. Целью работы является изучение культа лисы у башкир во всех его проявлениях в быту и хозяйственной жизни по данным фольклора, этнографии и других материалов.

\section{Лиса в устном народном творчестве,} обычаях и родовой этнонимии

В устном народном творчестве, ритуале и быте башкир лисицы (лисы) обладают теми же качествами, что и человек. Они разговаривают, мыслят, переживают, страдают, радуются по-человечески, дружат и действуют подобно людям. Так, в сказке «Иблис төлкө» («Лиса-дьявол») они обзаводятся хозяйством, в рассказе «Төлкө менән бесәй» («Лиса и кот») делают запасы продуктов, в байке «Торна менән төлкө» («Журавль и лиса») ходят друг к другу в гости как добрые соседи и друзья [БНТ 2009: 63-64, 66, 85] и т. д.

Общепризнано, что приписывание животным антропоморфных, а человеку зооморфных свойств является пережитком древнейших тотемических представлений о тождестве, единстве отдельных коллективов (стада) пралюдей и животных-тотемов, о способности их трансформироваться друг в друга [Авдеев 1959: 70; Семенов 1966: 332
333; и др.]. Вполне допустимо полагать, что в стародавние времена похожие суждения были характерны и для культа лисы.

Данное предположение подкрепляется богатыми фольклорными и этнографическими источниками. Например, в устном творчестве башкир зарегистрировано немало мифологических мотивов о метаморфозе лисицы (лиса) в человека и фольклорных героев - в лисицу (лиса). Так, в сказке «Караса-батыр» лиса выдает себя за дочь Куренмяс-хана [БНТ 1978: 128]. В устном рассказе «Котан-батыр» лисица превращается в дочь царя, остается вместо нее заложницей у аждахи (драконообразный персонаж башкирской мифологии), а потом, восстановив свое прежнее звериное обличье, убегает от него в лес [БНС 1941: 101-102].

В сказании «Бире кызы Бирәнһылыу» («Биранхылу - дочь бире») лисица могла обрести вид девушки, а в другой раз выдает себя за муллу (исламский служитель культа) [БНТ 1976а: 144-148].

В башкирской легенде «Золотой волос» в изложении П. П. Бажова молодой охотник погнался за лисицей, которую никак не мог подстрелить. Она ткнулась носом в землю, поднялась сухонькой старушкой, няней Златовласки [Бажов 1997: 398-405].

Лиса загадывается как девушка и в следующих башкирских загадках:
«Кызыл билле кыз килде,

Кыланды ла ювалды»».

«Кылансык кыз̧ кырзза йөрөй, Кыр тауывын кыра йөрөй».
'Пришла девица с красной талией Пококетничала и исчезла’.

'Кокетливая девица гуляет по полю, Истребляет серых куропаток'.

[БНТ 2007: 124].
Есть веские основания думать, что в прошлом башкирам были присущи и предрассудки о способности людей обернуться лисицей (лисом). М. Х. Мингажетдинов, изучая персонажи башкирских волшебных сказок, отмечает, что их герои - чудесные мужчины и женщины часто выступают в образе диких животных - медведя, волка, лисы и др. [Минһажетдинов 1971: 123].

Как нам представляется, в пользу данного высказывания говорят и вышеописанные случаи перевоплощения лисы (лиса) в людей, которые в свою очередь сами вновь превращаются в лисицу (лиса). Данное суждение подкрепляется и практикой но- шения в недавнем прошлом молодыми башкирскими мужчинами головного убора из лисьей шкуры или лап с пришитыми к задней части головного убора лисьим хвостом (вариант: двумя хвостами) или лисьей мордочки [Шитова 1995: 93].

Как известно, первобытные люди верили в возможность принять облик почитаемого животного, накинув на плечи или натянув на свою голову его шкуру (морду, рога и т. п.) [Илимбетова, Илимбетов 2012: 39-40, 79-80, 82-84, 292]. Вполне допустимо полагать, что и башкирский обычай ношения шапок из лисьей шкуры с хвостами или мордочки является рудиментом древне- 
го обряда трансформации человека в тотемного животного - в лису.

В представлениях башкир сохранились не только дериваты взаимного отождествления человека и лисы, но и отголоски мировоззрения о генезисе отдельных этнических общностей от лисы. Так, в составе юмран-табынцев Александровского района Оренбургской области [Агишева 2005], балыкчинцев Аскинского района Республики Башкортостан (РБ) [Камалов, Камалова 2007: 122, 137], кошсинцев Артинского района Свердловской области [Кузеев 1957: 48-57] и гайнинцев Бардымского района Пермского края [Миржанова 1991: 241] взяты на учет родовые подразделения под названием төлкө ('лиса'). Есть достаточно оснований отнести эти этнонимы к реликтам веры охотников, рыболовов и собирателей древнекаменного века в кровнородственные связи между отдельными группами людей и лисом-тотемом.

Общепризнанно считать, что на заре человеческой истории с формированием идеи о тождестве отдельных групп людей и определенных видов животных их начали воспринимать как субъекты единой общности, в результате чего зоонимы тотемных животных стали и этнонимами, и коллективными антропонимами тотемных групп людей [Белков 2004: 136-138; Семенов 1966: 332-333; и др.].

Подобные идеи послужили той базой, на основе которых сложились убеждения о родстве человека и тотемного животного, о генерировании их друг от друга. Поэтому такие этнонимы сопровождались, как правило, генеалогическими мифами о порождении той или иной тотемной группы людей от зооморфного тотемического предка. Вполне правомерно строить гипотезу, что и вышерассмотренные башкирские микроэтнонимы төлкө ('лиса') когда-то имели дополнения в виде генеалогических легенд о происхождении их носителей от лисы тотемического предка или лисицы-праматери.

В фольклорных и бытовых традициях башкир лиса как тотемический предок наделяется необыкновенными дарованиями оказать благотворное влияние на жизнь и судьбы людей. Так, по поверьям башкир Учалинского района РБ, лисы способны предвидеть ход событий [ФЭМ 2012: 109].
В мифе «Хәйләкәр төлкө» («Хитрая лиса») бежавший от охотников волк просит старика-лесоруба спрятать его. Рубщик леса засовывает зверя в мешок, вешает его на дерево и, когда преследователи уходят, выпускает хищника на волю. Неблагодарный зверь грозится съесть своего спасителя. Тут появляется лиса, она, узнав суть дела, просит волка показать, как дровосек выручил его из беды. Как только бирюк залезает в торбу, лиса велит мужику завязать мешок и унести его домой [БНТ 2009: 114-115].

В рассказе «Ас айыу, төлкө, егет» («Голодный медведь, лиса, парень») лиса спасает дровосека от лап медведя-людоеда. Лесорубу удается при помощи хитрой лисицы крепко завязать косолапого веревкой к телеге и отдубасить его колом [БНТ 1976а: 54].

В сказке «Изгелеккә-изгелек» («Добром за добро») лиса вызволяет легковерного рубщика леса из отчаянного положения: он по своей простоте освобождает из-под тяжелого камня змею, которая обещает не жалить его. Но стоило человеку приподнять камень, змея тут же обвивается вокруг его шеи. Встретившаяся им лиса хитростью добивается того, что змея ложится на прежнее место, а человек придавливает ее тем же камнем. Лиса говорит змее: «Коль не умеешь отвечать добром за добро, лежи здесь, пока не сдохнешь!» [Башкирский фольклор 1995: 158-159].

В новелле «Ике бер туған» («Два брата») звери-помощники егета, в частности, лиса, оживляют убитого героя, зализав его раны [БНТ 1976б: 164-166].

В волшебном рассказе башкир Учалинского района РБ «Шәғәле» («Шагали») мальчик, убегая от мяскяй-людоедки, взбирается на вершину громадного дерева. Людоедка начинает рубить дерево. Но валить его ей мешает лиса. Она подходит к ней и говорит: «Дай-ка помогу тебе. А то, гляжу, ты устала». Мяскяй соглашается, отдает ей топор и ложится спать под деревом. Лиса лижет подрубленный ствол - заруб в тот же миг затягивается, бросает топор в озеро и убегает прочь. Выспавшаяся мяскяй вновь начинает рубить дерево, но тут прибегают собаки Шагали и разрывают кровопийцу на части [БНТ 1976а: 190-197].

Сказка аналогичного содержания («Алтын ашык» / «Золотая бабка») записана и у башкир Хайбуллинского района [Кунакасо- 
ва 2005]. В мифе «Малай менән кызыкай» («Мальчик и девочка») брат с сестренкой теряются в лесу, лиса становится их верной спутницей, ловит им на пропитание плавающую в озере утку, охраняет мальчика от преследовавших его змей, дважды вырывает его из лап смерти [Рухи мирас̧ 2008: 19-23].

В фольклорной прозе «Алтын кауырhын» («Золотое перо») благодарная лиса советует егету не притрагиваться к золотому перу, иначе, мол, много горя хлебнешь. Она подсказывает юноше, где обитают золотая птица и волшебный морской конь, как добраться туда и поймать (укротить) их [БНТ 1978: 170-181].

В эпосе «һүңғы һартай» («Последний из рода сартай») сообщается, что тамгой, знаком собственности башкирского рода «hартай» («соловый стригунок»), был «хвост лисицы» [БНТ 1999: 289]. Возможно, в древности у сартаевцев лисица числилась покровительницей их рода, охранительницей родовой собственности. Кстати, необходимо отметить, что башкиры приписывали чудодейственные качества и другим частям лисицы. Так, бурзяне Бурзянского района РБ, чтобы обезопасить жизнь и здоровье малолетних детей, вешали к их колыбели лисий клык. Надежным магическим свойством обладает, по их мнению, и антропоним «Төлкөбай» (досл. төлкө 'лиса' + бай 'богатый': такое имя давали новорожденному ребенку при смерти предыдущих младенцев в семье. Последний обычай был известен и в Салаватском районе РБ [ПД Илимбетова 1966: 6, 31].

Лиса фигурирует в амплуа поборницы людей и в бытовых традициях башкир. В этом плане представляют определенный интерес архивные данные о том, что в прошлом волостное начальство (а в более ранние времена, возможно, и родоплеменные вожди) носило нагрудный знак с изображением лисьей головы [НА УФИЦ РАН. Ф. 3. Оп. 23. Ед. хр. 5].

На наш взгляд, апотропейную функцию выполнял и бронзовый колокольчик с изображением лисьих голов, обращенных в противоположные стороны [Ахмеров 1996: 31-32]. По всей видимости, он был предметом шаманского культа, который защищал его, или помогал ему при камлании и проведении других колдовских обрядов. По мне- нию исследователей, удвоение символа (на нашем примере, головы лисы) усиливало охранительную силу апотропея, защищало его владельца от злых сил со всех сторон [Голубева 1979: 38; Обыденнов, Миннигулова 1985: 109]. Вот почему у башкир положительную нагрузку несли не только изображения лисицы, но и встреча с ней наяву или во сне. Так, башкиры Большеглушицкого района Самарской области благосклонно интерпретировали встречу в пути с лисой это к желанному исходу дела [һамар 2008: 126]. Особенно много суеверий зафиксированы в связи со сновидением о лисе. Если приснится лиса, то башкиры Салаватского, Кигинского, Чишминского, Туймазинского, Кугарчинского районов РБ воспринимали его как доброе предзнаменование (изгелеккә) [ПД Илимбетова 1966: 10, 22, 35, 48].

\section{Лиса - покровительница семьи, рожениц и младенцев}

В фольклорно-мифологических материалах башкир лиса предстает как необычайная патронесса плодородия, попечительница брака, семьи, рожениц и младенцев. В частности, в башкирской сказке «Төлкө менән егет» («Лиса и юноша»), записанной в Давлекановском, Илишевском, Ишимбайском и Стерлитамакском районах РБ, добродетельная лиса хитрыми проделками женит бедного юношу на дочери бая и находит для молодоженов хороший дом. Лиса помогает героям народных произведений «Караса-батыр», «Биранхылу - дочь бире» и «Золотой волос» обвенчаться с дочерьми Куренмяс-хана, царя бесов или мифического Полоза, хозяина подземных кладовых драгоценных металлов. В новелле айлинских башкир Аргаяшского района Челябинской области «Акыллы бесәй менән Таз̧» («Умный кот и Плешивый») десять лисиц соглашаются быть калымной платой за царскую дочь, и плешивый становится зятем царя [БНТ 1976а: 97-101, 341].

Связь лисицы с созданием семьи, установлением брачных отношений всплывает и в поверье башкир Кугарчинского района РБ о том, что если девушке или юноше приснится лисица - это к замужеству или женитьбе [ПД Илимбетова 1966: 42].

В легенде башкир Учалинского района РБ «Серле күл» («Таинственное озеро») говорится, что во время сильного наводне- 
ния от проливного дождя некая беременная женщина оказывается одна в безбрежном водном пространстве. Ей удается ухватиться за выступ камня. Она услышала визг лисы, сидящей на толстом суке огромной лиственницы. Женщина забирается на тот же сук дерева и, прижавшись спиной к лисе, рожает сына. Вдруг прекращается ливень, появляется солнце, сходятся воды, образуя озеро, возникает суша. Лиса, радостно взвизгнув, прыгает на землю и исчезает. Молодая женщина с сыном также спускаются вслед за лисой на берег озера и обосновываются в той местности [ФЭМ 2012: 109]. Как нам кажется, данная легенда является позднейшим переложением древнейшего эсхатологического мифа о мировом потопе, в котором в живых остаются только беременная женщина и лиса. Лиса показывает беременной женщине путь для спасения, выполняет миссию повитухи и показывает молодой матери пригодность образовавшейся суши для проживания людей и животных.

\section{Лиса в традиционной медицине}

Рудименты умозрений о лисе как о защитнице и опекунше людей укоренились в традиционной медицине башкир. Так, в магических приемах лечения различных недугов широко использовались те или иные части тела лисы и вырабатываемые в ее организме секреты. К примеру, при болезни детей рахитом (өсйән) им давали пить настой, изготовленный из высушенной лисьей желчи $(y m)$. Раствор порошка, соскобленного от высушенной лисьей желчи, считался лекарственным средством при лечении малярии (manмa) [ПД Илимбетова 1966: 37], такую микстуру принимали и от кашля (юткерек) [ЭМ 2006: 146].

При ангине (көмбә) лисьей желчью смазывали горло пациента, такую процедуру делали на больное место при появлении на теле опухолей и нарывов (яман шеш). Лисью желчь капали в глаза при катаракте (күззгә ак haльly). При эпилепсии (быума) башкиры носили при себе амулет (бетеу), написанный лисьей желчью. При врачевании легочных заболеваний (үnкә ауылрыуыл) рекомендовалось есть лисье мясо. В Бурзянском районе РБ больного малярией кормили лисьим мясом, купали его в лисьем бульоне и клали рядом с ним лисий череп. Башкиры Баймакского района РБ при ревматизме обертывали ноги лисьей шкурой [ПД Илимбетова 1966: 64].

\section{Лиса в религиозно-мистических воззрениях и бытовых традициях}

Как известно, в процессе дальнейшего развития тотемизма, представления о тотемических предках эволюционировали к образам зооантропоморфных племенных и межплеменных божеств-демиургов, культурных героев и высших духов - покровителей природной и социальной сфер. Этнографические и фольклорно-мифологические материалы показывают, что подобного пути перехода к новому состоянию не избежал и культ лисы. В этом контексте нельзя не отметить работы Р. Ю. Аккубекова и Р. Т. Алмухановой, в которых выдвигаются тезисы о том, что в башкирской мифологии лиса олицетворяет собою зооморфное божество, хозяйку природы, и, благодаря рыжему (огненному) цвету, ее связывают с солнцем [Аккубеков 2006: 10; Алмуханова 2011: 36].

Божественная ипостась лисы находит отражение и в мотивах негативного ее восприятия в устных традициях ряда народов мира. Ведь прежде чем стать отрицательными фольклорно-мифологическими персонажами, все зооморфные тотемические предки ценились как полубожественные существа, олицетворение сакральных начал. Они стали отрицательными типами в результате борьбы мировых религий (буддизма, иудаизма, ислама и христианства) с пережитками первобытных религиозных верований и культов в сознании людей. Так, по суевериям башкир, обитающие в пещерах оборотни, вредоносные силы, духи отдельных видов болезней, злокозненные дивы могут принимать вид черно-бурой лисицы [Даль 1989: 172-188; Хисамитдинова 2010: 303].

Реликты культа лисы проявляются и в бытовых традициях башкир. Несомненно, в их число входит сольный танец «Төлкө бейеүе» («Танец лисы»). Исполнитель пляски в шапке с пришитыми двумя лисьими хвостами стремился воспроизводить в танце все движения и повадки ловкой, увертливой и хитрой лисы [Солтангәрәева, Баймырззина 2009: 50]. Не исключено, что данный 
танец был составной частью, компонентом какого-то обряда, праздника, посвященного лисице. К такому выводу побуждает нас выявление его некоторых элементов у самых различных народов Евразии и Америки.

В религиозно-мистических воззрениях башкир лиса как сакральное существо значится в качестве табуированного животного. К примеру, во время охоты на лис нельзя было произносить вслух зооним төлкө ('лиса'). На охотничьем жаргоне ее (его) называли иносказательно көлтә койрож 'пушистохвостая' или йылтыр күз 'блестящеглазая' [Киреев 1976: 72].

По суевериям башкир Учалинского района, нельзя трогать (обижать) лису, надо остерегаться от ее (его) заклятия [ФЭМ 2012: 109]. Башкиры Александровского района Оренбургской области включают в список запрещенных для потребления в пищу мясо лисы [Агишева 2005]. В записанной в 1770 г. И. И. Лепехиным легенде о Туратау говорится, что на той горе некий человек «гонялся за лисицей без всякого обета.., был растерзан пегим медведем» [Лепехин 1802: 33].

\section{Заключение}

Исходя из вышеизложенных материалов, можно сделать вывод, что в фольклоре, религиозно-мистических взглядах башкир лисы наделяются теми же биологическими, психическими и физическими качествами, что и человек. Они разговаривают, мыслят, переживают, страдают, радуются, дружат по-человечески, ведут человеческий образ жизни. В устном народном творчестве башкир сохранилось немало пережитков тотемических пред-

\section{Источники}

НА УФИЦ - Научный архив УФИЦ РАН. Ф. 3. Оп. 23. Ед. хр. 5.

ПД Илимбетова 1966 - Полевой дневник Ф. Ф. Илимбетова. 1966 // Архив семьи Илимбетовых.

\section{Полевые материалы автора}

Агишева 2005 - Информант Рамзия Агишева, 1939 г. р. Запись 2005 г., д. Канчирово Александровского района Оренбургской области.

Кунакасова 2005 - Информант Алтынбика Кунакасова, 1936 г. р. Запись 2005 г., с. Акъяр Хайбуллинского района Республики Башкортостан. ставлений о тождестве, единстве человека и лисы, о способности их перевоплощаться друг в друга. Мифологии башкир были присущи мотивы о происхождении отдельных этнических общностей (родов и родовых подразделений) от лисы. Лиса как тотемический предок выступает в роли покровительницы, защитницы, советницы и помощницы людей, дарит им жизнь, здоровье, благополучие и семейное счастье. Видимо, в основе сказки «Таинственное озеро» лежит древнейший эсхатологический миф о всемирном потопе, где лиса фигурирует как попечительница беременной женщины, показывает ей путь к спасению, способствует ей в разрешении от бремени ребенком, будущим предком отдельного родового подразделения, отправляется в разведку проверить пригодность образовавшейся суши для проживания людей и животных. В устной словесности башкир имеются косвенные свидетельства о признании лисы зооморфным божеством, хозяйкой природы и олицетворением солнца. В бытовых традициях, в народной хореографии прослеживаются следы тотемического обряда, посвященного чествованию лисы как тотема и тотемического предка. В обычаях и поверьях башкир лиса как сакральное существо была табуированным животным. Мотивы негативной характеристика лисы в фольклоре, обычаях и суевериях связаны с тем, что в древности не все этнические образования, вошедшие в состав башкирского народа, почитали лису как тотем и тотемического предка, и эти воззрения нашли отражение в их религиозно-мифологических представлениях.

\section{Sources}

Field Diary of Fattah F. Ilimbetov. 1966. At: Family Archive of the Ilimbetovs. (In Bash.)

Ufa Federal Research Centre of the RAS, Scientific Archive. Coll. 3. Cat. 23. Item 5. (In Russ.)

\section{Author's Field Data}

Informant: Altynbika Kunakasova, b. 1936 (Akyar, Khaybullinsky District, Republic of Bashkortostan). Rec. in 2005. (In Bash.)

Informant: Ramzia Agisheva, b. 1939 (Kanchirovo, Aleksandrovsky District, Orenburg Oblast). Rec. in 2005. (In Bash.) 


\section{Литература}

Авдеев 1959 - Авдеев А. Д. Происхождение театра. Элементы театра в первобытнообщинном строе. М.; Л.: Искусство, 1959. 266 с.

Аккубеков 2006 - Аккубеков Р. Ю. Башкирские народные сказки о животных: типология и взаимосвязь с письменными источниками: автореф. дис. ... канд. филол. наук. Казань, 2006. $28 \mathrm{c}$.

Алмуханова 2011 - Алмуханова Р. Т. Отражение солярного культа в казахском и башкирском фольклоре // Этногенез. История. Культура. I Юсуповские чтения: мат-лы Межд. науч.-практ. конф., посв. памяти Р. М. Юсупова (г. Уфа, 17-19 ноября 2011 г.). Уфа: ИИЯЛ УНЦ РАН, 2011. С. 36-40.

Ахмеров 1996 - Ахмеров Р. Б. Об истоках декоративно-прикладного искусства башкирского народа. Уфа: Китап, 1996. 64 с.

Бажов 1997 - Бажсов П. П. Золотой волос // Башкирия в русской литературе: в 6 т. / сост. М. Г. Рахимкулов. Т. 4. Уфа: Китап, 1997. C. 398-405.

Белков 2004 - Белков П. Л. Миф и тотем в традиционном обществе аборигенов Австралии. СПб.: МАЭ РАН, 2004. 288 с.

БНС 1941 - Башкирские народные сказки / запись и перев.: А. Г. Бессонов; ред., введен. и прим.: Н. К. Дмитриев; под общ. ред. акад. И. Ю. Крачковского Уфа: Башгосиздат, $1941.368 \mathrm{c}$.

БНТ 1976а - Башкирское народное творчество. Сказки. Кн. 1. Уфа: Башк. кн. изд-во, 1976. $380 \mathrm{c.}$

БНТ $1976 б$ - Башкирское народное творчество. Сказки. Кн. 2. Уфа: Башк. кн. изд-во, 1976. $376 \mathrm{c.}$

БНТ 1978 - Башкирское народное творчество. Сказки. Кн. 3. Уфа: Башк. кн. изд-во, 1978. $351 \mathrm{c.}$

БНТ 1999 - Башкирское народное творчество. Т. 4. Эпос. Уфа: Китап, 1999. 400 с.

БНТ 2007 - Башкирское народное творчество. Т. 9. Загадки. Уфа: Китап, 416 с.

БНТ 2009 - Башкирское народное творчество. Т. 13. Сказки о животных. Уфа: Китап, 2009. $200 \mathrm{c}$.

Башкирский фольклор 1995 - Башкирский фольклор. Исследования и материалы / сост. Б. С. Баимов. Вып. 2. Уфа: ИИЯЛ УНЦ РАН, 1995. 204 c.

Голубева 1979 - Голубева Л. А. Зооморфные украшения финно-угров. М.: Наука, 1979. $112 \mathrm{c}$.
Даль 1989 - Даль В. И. Башкирская русалка // Башкирия в русской литературе: в 6 т. / сост. М. Г. Рахимкулов. Уфа: Башк. кн. изд-во, 1989. T. 1. C. $172-188$.

Илимбетова, Илимбетов 2012 - Илимбетова А. Ф., Илимбетов Ф. Ф. Культ животных в мифоритуальной традиции башкир. 2-е изд. Уфа: АН РБ, Гилем, 2012. 704 с.

Камалов, Камалова 2007 - Камалов А. А., Камалова Ф. У. Башкорт теленең тарихи-этимологик топонимик һүзлеге (= Историкоэтимологический топонимический словарь башкирского языка). Өфө: Китап, 2007. 3316.

Киреев 1976 - Киреев А. Н. (Кирей Мэргэн). Башкорт халкының йола фольклоры буйынса күзәтеүзәр (= Исследования обрядового фольклора башкирского народа) // Әзəбиәт. Фольклор. Әзəби мирас (= Литература. Фольклор. Литературное наследие). Кн. 2. Өфө: Изд-во Баш. гос. ун-та, 1976. С. 72-75.

Кузеев 1957 - Кузеев Р. Г. Очерки исторической этнографии башкир. Ч. 1. Родоплеменные организации башкир в XVII-XVIII вв. Уфа: Башк. кн. изд-во, 1957. 183 с.

Лепехин 1802 - Лепехин И. И. Дневные записки путешествия академика и медицины доктора Ивана Лепехина, по разным провинциям Российского государства в 1770 году. СПб.: Тип. Имп. акад. наук, 1802. Ч. 2. 345 с. Минһажетдинов 1971 - Минһажетдинов М. X. Башкорт әкиәттәрен тарихи-сағыштырма өйрәнеүгә карата (= К историко-сравнительному изучению башкирских сказок) // Агидель. 1971. № 9. С. 123-125.

Миржанова 1991 - Миржанова С. Ф. Северо-западный диалект башкирского языка (формирование и современное состояние). Уфа: Башк. кн. изд-во, 1991. 296 с.

Обыденнов, Миннигулова 1985 - Обыденнов М. Ф., Миннигулова Ф. М. Древнее искусство Башкирии. Уфа: Башк. кн. изд-во, 1985. $150 \mathrm{c}$.

Рухи мирас 2008 - Рухи мирас̧: Свердловск башкорттарының фольклоры (= Духовное наследие: фольклор свердловских башкир). Уфа: Дел. дин., 2008. 256 с.

Семенов 1966 - Семенов Ю. И. Как возникло человечество. М.: Наука, 1966. 576 с.

Солтангәрәева, Баймырззина 2009 - Солтангәрәева Р. Ә., Баймырззина Г. В. Башкорт бейеү фольклоры: боронғоһо һәм бөгөнгөһө (= Танцевальный фольклор башкир: прошлое и настоящее). Өфө: Белая река, 2009. 98 б. 
ФЭМ 2012 - Фольклор экспедицияһы материалдары-2011: Учалы районы (= Материалы фольклорной экспедиции-2011: Учалинский район). Уфа: ИИЯЛ УНЦ РАН, 2012. 156 с.

Хисамитдинова $2010-$ Хисамитдинова Ф. Г. Мифологический словарь башкирского языка. М.: Наука, 2010. 456 с.

һамар 2008 - hамар, һарытау өлкәһе башкорттарының рухи хазинаһы (= Духовное бо-

\section{References}

Akhmerov R. B. Bashkir Decorative and Applied Arts: Origins Revisited. Ufa: Kitap, 1996. 64 p. (In Russ.)

Akkubekov R. Yu. Bashkir Animal Tales: Typology and Interrelation with Written Sources. Cand. Sc. (philology) thesis abstract. Kazan, 2006. 28 p. (In Russ.)

Almukhanova R. T. The solar cult in Kazakh and Bashkir folklore. In: Ethnogenesis. History. Culture. $1^{\text {st }}$ Yusupov Readings. Conference Proceedings (Ufa; November 17-19, 2011). Ufa: Institute of History, Language and Literature (Ufa Federal Research Centre of RAS), 2011. Pp. 36-40. (In Russ.)

Avdeev A. D. Origins of Theatre. Theatrical Elements in Prehistoric Society. Moscow, Leningrad: Iskusstvo, 1959. 266 p. (In Russ.)

Baimov B. S. (comp.) Bashkir Folklore: Studies and Materials. Ufa: Institute of History, Language and Literature (Ufa Scientific Center of RAS), 1995. Vol. 2. 204 p. (In Bash and Russ.)

Bashkir Folklore. Vol. 13: Animal Tales. Ufa: Kitap, 2009. 200 p. (In Bash. and Russ.)

Bashkir Folklore. Vol. 4: Epic. Ufa: Kitap, 1999. 400 p. (In Bash. and Russ.)

Bashkir Folklore. Vol. 9: Riddles. Ufa: Kitap, 416 p. (In Bash. and Russ.)

Bashkir Folklore: Tales. Vol. 1. Ufa: Bashkir Book Publ., 1976. 380 p. (In Bash. and Russ.)

Bashkir Folklore: Tales. Vol. 2. Ufa: Bashkir Book Publ., 1976. 376 p. (In Bash. and Russ.)

Bashkir Folklore: Tales. Vol. 3. Ufa: Bashkir Book Publ., 1978. 351 p. (In Bash. and Russ.)

Bazhov P. P. The Golden Hair. In: Rakhimkulov M. G. (comp.) Bashkiria in Russian Literature. In 6 vols. Ufa: Kitap, 1997. Vol. 4. Pp. 398-405. (In Russ.)

Belkov P. L. Myth and Totem in Aboriginal Australian Society. St. Petersburg: Peter the Great Museum of Anthropology and Ethnography (RAS), 2004. 288 p. (In Russ.) гатство башкир Самарской и Саратовской областей) / сост.: Р. А. Султангареева и др. Уфа: Дел. дин., 2008. 284 с.

Шитова 1995 - Шитова С. Н. Башкирская народная одежда. Уфа: Китап, 1995. 240 с.

ЭМ 2006 - Экспедиция материалдары - 2003: Йылайыр районы (= Экспедиционные материалы - 2003: Зилаирский район). Уфа: Издво МО РБ, 2006. 251 с.

Dal V. I. The Bashkir Rusalka. In: Rakhimkulov M. G. (comp.) Bashkiria in Russian Literature. In 6 vols. Ufa: Bashkir Book Publ., 1989. Vol. 1. Pp. 172- 188. (In Russ.)

Expedition Materials - 2003: Zilairsky District (Republic of Bashkortostan). Ufa: Ministry of Education (Republic of Bashkortostan), 2006. 251 p. (In Bash.)

Golubeva L. A. Zoomorphic Decorative Items of Finno-Ugrians. Moscow: Nauka, 1979. 112 p. (In Russ.)

Ilimbetova A. F., Ilimbetov F. F. Bashkir Myth and Ritual Tradition: Animal Cult. $2^{\text {nd }}$ ed. Ufa: Bashkortostan Academy of Sciences, Gilem, 2012. 704 p. (In Russ.)

Kamalov A. A., Kamalova F. U. Bashkir Toponymic Dictionary: Historical Etymologies. Ufa: Kitap, 2007. 331 p. (In Bash.)

Khisamitdinova F. G. Mythological Dictionary of the Bashkir Language. Moscow: Nauka, 2010. 456 p. (In Russ.)

Kireev A. N. (Kirei Mergen) Studies in Bashkir ritual folklore. In: Literature. Folklore. Literary Heritage. Ufa: Bashkir State University, 1976. Vol. 2. Pp. 72-75. (In Bash.)

Krachkovsky I. Yu. (ed.) Bashkir Folk Tales. A. Bessonov (rec., transl.), N. Dmitriev (ed., foreword, comments). Ufa: Bashkir Book Publ., 1941. 368 p. (In Russ.)

Kuzeev R. G. Essays on Bashkir Historical Ethnography. Vol. 1: Bashkir Clan and Tribal Units, $17^{\text {th }}-18^{\text {th }}$ Centuries. Ufa: Bashkir Book Publ., 1957. 183 p. (In Russ.)

Lepekhin I. I. Across Different Provinces of the Russian State: 1770 Travel Notes of Ivan Lepekhin, Academician and Medical Doctor. St. Petersburg: Imperial Academy of Sciences, 1802. Part 2. 345 p. (In Russ.)

Materials of 2011 Folklore Expedition: Uchalinsky District (Republic of Bashkortostan). Ufa: Institute of History, Language and Literature (Ufa Scientific Center of RAS), 2012. 156 p. (In Bash.) 
Mingazhetdinov M. Kh. Bashkir tales: a comparative historical study. Agidel'. 1971. No. 9. Pp. 123125. (In Bash.)

Mirzhanova S. F. Northwestern Dialect of the Bashkir Language: Genesis and Present-Day State. Ufa: Bashkir Book Publ., 1991. 296 p. (In Russ.)

Nazershina F. et al. Spiritual Heritage: Folklore of Sverdlovsk Bashkirs. Ufa: Del. Din., 2008. 256 p. (In Bash.)

Obydennov M. F., Minnigulova F. M. Ancient Arts of Bashkiria. Ufa: Bashkir Book Publ., 1985. 150 p. (In Russ.)

Semenov Yu. I. How Mankind Emerged. Moscow: Nauka, 1966. 576 p. (In Russ.)

Shitova S. N. Traditional Bashkir Clothing. Ufa: Kitap, 1995. 240 p. (In Russ.)

Sultangareeva R. A., Yaykarova Z. I. (eds.) Spiritual Wealth of Samara and Saratov Bashkirs. Ufa: Del. Din., 2008. 284 p. (In Bash.)

Sultangareeva R. A., Baimurzina R. A. Bashkir Dance Folklore: Past and Present. Ufa: Belaya Reka, 2009. 98 p. (In Bash.) 